\title{
Studies on an alkali-thermostable xylanase from Aspergillus fumigatus MA28
}

\author{
Bijender Kumar Bajaj • Massarat Abbass
}

Received: 3 April 2011/Accepted: 16 July 2011/Published online: 13 August 2011

(C) The Author(s) 2011. This article is published with open access at Springerlink.com

\begin{abstract}
An alkalitolerant fungus, Aspergillus fumigatus strain MA28 produced significant amounts of cellulase-free xylanase when grown on a variety of agro-wastes. Wheat bran as the sole carbon source supported higher xylanase production $(8,450 \mathrm{U} / \mathrm{L})$ than xylan $(7,500 \mathrm{U} / \mathrm{L})$. Soybean meal was observed to be the best nitrogen source for xylanase production $(9,000 \mathrm{U} / \mathrm{L})$. Optimum medium $\mathrm{pH}$ for xylanase production was $8(9,800 \mathrm{U} / \mathrm{L})$, though, significant quantities of the enzyme was also produced at $\mathrm{pH} 7$ (8,500 U/L), 9 (8,200 U/L) and 10 (4,600 U/L). The xylanase was purified by ammonium sulphate precipitation and carboxymethyl cellulose chromatography, and was found to have a molecular weight of $14.4 \mathrm{kDa}$ with a $V_{\max }$ of $980 \mu \mathrm{mol} / \mathrm{min} / \mathrm{mg}$ of protein and a $K_{\mathrm{m}}$ of approximately $4.9 \mathrm{mg} / \mathrm{mL}$. The optimum temperature and $\mathrm{pH}$ for enzyme activity was $50{ }^{\circ} \mathrm{C}$ and $\mathrm{pH} 8$, respectively. However, the enzyme also showed substantial residual activity at $60-70{ }^{\circ} \mathrm{C}(53-75 \%)$ and at alkaline $\mathrm{pH} 8-9$ (56-88\%).
\end{abstract}

Keywords Xylanase $\cdot$ Alkali-thermostable Aspergillus fumigatus · Production · Agro-residues . Purification

B. K. Bajaj · M. Abbass

School of Biotechnology, University of Jammu, Jammu 180 006, India

Present Address:

B. K. Bajaj $(\square)$

Biotechnology and Fermentation Group, Department of Animal Sciences, Gerlaugh Hall, Ohio Agricultural Research and Development Centre (OARDC), The Ohio State University, 1680 Madison Avenue, Wooster, OH 44691, USA

e-mail: bkbajaj1@ rediffmail.com

\section{Introduction}

Xylan, consisting of a backbone of $\beta-(1 \rightarrow 4)$ linked D-xylopyranosyl units with various substitutions, is the second most abundant biopolymer in plant cell walls after cellulose, and represents the major polysaccharide of hemicelluloses. Endo- $\beta-1,4-x y l a n a s e$ (EC 3.2.1.8) and $\beta$-xylosidase (EC 3.2.1.37) are the key enzymes involved in the hydrolysis of the xylan backbone although some other enzymes are required for debranching (Kuhad and Singh 1993). Xylanases have high potential for biotechnological applications. For instance, xylanases can be used to improve the digestibility and nutritional value of ruminant fodder, to facilitate composting process, to improve the quality of bread, to develop environmentally friendly pulp bleaching process and to transform lignocellulosic materials to fermentable products (Kuhad and Singh 1993; Beg et al. 2001; Maalej et al. 2009; Singh et al. 2011). In pulp and paper industry, xylanase-treatment of kraft pulp reduces the dependence on the use of hazardous chemicals required for bleaching but in this case xylanases must be free from any cellulase activity (Kuhad and Singh 1993; Beg et al. 2001; Singh et al. 2011).

For bulk production of industrial enzymes, the cost of the substrate constitutes one of the most important factors in determining the overall economy of the process. Agriculture-based wastes such as wheat bran, sawdust, rice straw, corncob, wood husk and maize bran are excellent low-cost substrates for xylanase production (Bajaj and Singh 2010; Murthy and Naidu 2010); India, being an agriculture-based economy, generates huge quantum of agro-residues which are difficult to dispose off, and their use as substrates for xylanase production will not only combat environmental pollution but will also reduce the cost of enzyme production. 
Xylanases are produced by many bacterial and fungal species but most of the enzymes characterized to date are optimally active only at acidic, neutral or slightly alkaline $\mathrm{pH}$, and at temperature between 40 and $60{ }^{\circ} \mathrm{C}$. These characteristics fall short of the required criteria for industrial applications and to fulfil the requirement of more robust xylanases, recently more thermostable and alkalistable xylanases have been reported (Sharma and Bajaj 2005; Sudan and Bajaj 2007; Nair et al. 2008; Bajaj and Singh 2010; Murthy and Naidu 2010; Singh et al. 2011). Fungi have been studied widely for thermo- and alkalistable xylanases over bacteria as they offer many advantages-fungi are biodiverse, produce extracellular enzymes which obviates the need for cell breakage, can efficiently utilize complex agro-industrial wastes as substrates for enzyme production, produce higher amounts of enzymes, are more tolerant and better adapted to changes in the environmental factors for growth and produce several auxiliary enzymes which are important in debranching of substituted xylans (Bakri et al. 2010; Haltrich et al. 1996; Sudan and Bajaj 2007; Bakri et al. 2010; Pal and Khanum 2010; Shuvaeva and Sysoeva 2010).

We report here our study of a thermo- and alkali-stable xylanase from Aspergillus fumigatus MA28.

\section{Materials and methods}

Chemicals, media and medium components

All the chemicals, media, and media components used in this study were procured from HiMedia Laboratories Ltd., Ranbaxy Fine Chemicals Ltd., Qualigens Fine Chemicals Ltd. (India) and Sigma Chemicals Ltd. and Merck and Co. Inc. (USA).

\section{Isolation of xylanolytic fungi}

Samples of alkaline soil, soil samples beneath heaps of rice and wheat straw or sugarcane bagasse, cow dung manure, poultry waste, sawdust, among others, were collected from alkaline, hot and humid locations in the vicinity of decaying organic matter, and used for the isolation of xylanolytic fungi (Sudan and Bajaj 2007). Samples were suspended in saline $(0.85 \% \mathrm{NaCl})$ and suitable dilutions were spread-plated on potato-dextrose-agar (PDA) and plates were incubated at $30{ }^{\circ} \mathrm{C}$. Fungal colonies which appeared after $3-5$ days of incubation at $30^{\circ} \mathrm{C}$ were transferred from PDA to xylan agar medium. Xylan agar medium contained $(\mathrm{g} / \mathrm{L})$ : ammonium sulphate 3 , potassium dihydrogen phosphate 3 , ammonium acetate 6 , oat spelt xylan 5, agar 20; $\mathrm{pH} 8-10$ ). Plates were incubated at $30{ }^{\circ} \mathrm{C}$ for 3-5 days and colonies developed were assayed for their xylanase producing ability by Congo red staining (Sharma and Bajaj 2005). A total of 40 fungal isolates were examined for xylanolytic activity. Selected isolates were examined further for xylanase producing ability under submerged fermentation ( $\mathrm{pH} 8-9$ ). All fungal isolates were maintained on PDA slants at $4{ }^{\circ} \mathrm{C}$.

Growth, and enzyme production and assay from selected isolates

Selected xylanolytic fungal isolates were grown on PDA for 5 days and inoculated ( 3 discs of $3 \mathrm{~mm}$ each/100 mL) into enzyme production medium containing $(\mathrm{g} / \mathrm{L})$ : ammonium sulphate 3 , potassium dihydrogen phosphate 3 , ammonium acetate 6 , xylan $5, \mathrm{KCl} 0.5$, magnesium sulphate 0.5 , ferrous sulphate $0.1 ; \mathrm{pH} 8$ ) and fermentation was conducted in shaking-incubator (Innova, New Brunswick, USA) at $30{ }^{\circ} \mathrm{C}(180 \mathrm{rpm})$. After suitable intervals of time, samples were withdrawn and centrifuged at $10,000 \times \mathrm{g}$ for $10 \mathrm{~min}$ at $4{ }^{\circ} \mathrm{C}$ (Sigma $3 \mathrm{~K} 30$, UK). The pellet was dried to constant weight in a hot air oven maintained at $90{ }^{\circ} \mathrm{C}$ to determine the amount of biomass, and supernatant was assayed for xylanase, carboxymethyl cellulase (CMCase) and FPase (filter paper activity) activities. Xylanase activity was assayed by using xylan $(0.5 \% \mathrm{w} / \mathrm{v}$ in Tris buffer, $50 \mathrm{mM}, \mathrm{pH} 8$ ) as the substrate at $45{ }^{\circ} \mathrm{C}$. The reducing sugars released were assayed by dinitrosalicylic acid (DNSA) method using xylose as standard (Miller 1959). One unit of xylanase activity (IU) is defined as the enzyme necessary to release $1 \mu \mathrm{mol}$ of reducing sugar or xylose equivalent per min under assay conditions. CMCase and FPase were also assayed by employing DNSA method using carboxymethyl cellulose (CM-cellulose) and filter paper as substrates, respectively (Sudan and Bajaj 2007). One unit (IU) of CMCase or FPase was defined as the amount of enzyme required to release $1 \mu \mathrm{mol}$ of reducing sugar equivalent per min under assay conditions. Qualitative analysis of xylanolytic activity was done by using well plate assay. For this, the enzyme (70 $\mu \mathrm{l})$ was pipetted into wells of xylan agar plates. The wells were made using a $6 \mathrm{~mm}$ cork borer. The plates were incubated overnight at $30{ }^{\circ} \mathrm{C}$ and then stained with Congo red. Zones of clearance were suggestive of the presence of xylanase. Isolate MA28 which yielded maximum xylanase activity was selected for further studies.

Identification of the isolate MA28 was done by culture morphological and microscopic examination (Raper and Fennell 1965), and by internal transcribed spacer (ITS) sequence analysis. The ITS region of fungal rDNA which includes ITS 1, 5.8S and ITS 2 regions was amplified by using universal ITS region primers (ITS 1, $5^{\prime}$-TCC GTA GGT GAA CCTGCG G-3', and ITS 4, 5'-TCC TCC GCT TAT TGA TAT GC-3') (Bakri et al. 2010). The amplified 
DNA was sequenced directly (ABI Biosystems) and the sequence was aligned with the consensus fungal ITS sequences available in the GenBank (NCBI) using Mega BLAST. Multiple ITS sequence alignment was performed using Clustal W 2. The sequence was submitted to GenBank (NCBI) and accession number obtained (JN112377).

Xylanase production with different carbon and nitrogen sources

To test the effect of different carbon sources on xylanase production, xylan of the production medium was replaced with either of the different agro-based substrates $(10 \mathrm{~g} / \mathrm{L})$ namely, wheat bran, rice bran, sawdust, rice straw, powdered corncob, wood husk, maize bran, wheat flour mill waste or cotton seed cake as the sole carbon source. Prior to use, these substrates were crushed, sieved (mesh size 20), and steam hydrolyzed by autoclaving at 15 psi for $15 \mathrm{~min}$. To examine the effect of different nitrogen sources on xylanase production, the production media containing xylan $(5 \mathrm{~g} / \mathrm{L})$ was used with either of the following nitrogen sources $(5 \mathrm{~g} / \mathrm{L})$ : yeast extract, urea, soybean meal, ammonium sulphate, peptone, gelatin, tryptone, beef extract, potassium nitrate or ammonium nitrate. Five-day old fungal cultures grown on PDA were used to seed the media containing different carbon and nitrogen sources followed by incubation at $30^{\circ} \mathrm{C}$ with shaking (180 rpm). Samples withdrawn after various time intervals were assayed for activity of xylanase, CMCase and FPase.

Effect of initial medium $\mathrm{pH}$ on xylanase production

Production medium containing xylan $(5 \mathrm{~g} / \mathrm{L})$ as the carbon source and soybean meal $(5 \mathrm{~g} / \mathrm{L})$ as the nitrogen source pre-adjusted to $\mathrm{pH}$ between 5 and 10 with $\mathrm{NaOH}(0.1 \mathrm{M})$ or $\mathrm{HCl}(0.1 \mathrm{M})$, was used to determine the effect of initial medium $\mathrm{pH}$ on xylanase production. Growth was initiated by seeding the medium with a 5-day-old PDA grown culture followed by incubation at $30{ }^{\circ} \mathrm{C}$ with shaking (180 rpm).

\section{Xylanase purification}

Freshly developed enzyme was subjected to ammonium sulphate (AS) precipitation at different saturation levels $(20-100 \%)$. Each fraction was tested for protein content and xylanase activity. The fractions that had substantial xylanase activity were pooled, and dialyzed against phosphate buffer $(\mathrm{pH} 7)$ for $12 \mathrm{~h}$. Buffer was replaced with fresh one after every $4 \mathrm{~h}$ during dialysis. Dialyzed preparation was used for ion exchange chromatography. The CM-cellulose column $(3.5 \times 50 \mathrm{~cm})$ was equilibrated with
10 volumes of the equilibration buffer (Tris buffer, $10 \mathrm{mM}$, $\mathrm{pH} 9$ ), and the sample was loaded. Elution was carried out by using increasing concentrations of $\mathrm{NaCl}(0.25-1.0 \mathrm{M})$, and fractions collected were analysed for xylanase activity and protein content. Protein content in the samples was determined by the method of Lowry et al. (1951). The fraction with substantial activity was examined by Nativepolyacrylamide gel electrophoresis (PAGE) for zymogram study, and by sodium dodecyl sulphate-PAGE (SDSPAGE) for molecular weight determination (Sambrook et al. 1989). Acrylamide concentration in resolving gel and stacking gel was 12 and 5\%, respectively, and electrophoresis was performed at $100 \mathrm{~V}$ for $4 \mathrm{~h}$. Purified enzyme was loaded in duplicate on native gel, and after electrophoresis, the gel was cut vertically into two equal halves. For zymogram analysis, one half of the native gel was overlayered on agar plate containing agar $(1 \%, \mathrm{w} / \mathrm{v})$ and xylan $(0.5 \%, \mathrm{w} / \mathrm{v})$, and incubated at $50{ }^{\circ} \mathrm{C}$ for $1-2 \mathrm{~h}$, followed by Congo red staining of agar plate and observation for zone of clearance which is suggestive for positive zymogram reaction; and the other half of native gel was stained with coomassie brilliant blue (CBB) and observed for protein bands after destaining.

\section{Characterization of purified xylanase for some} properties

Kinetic parameters $\left(K_{\mathrm{m}}\right.$ and $\left.V_{\max }\right)$ of purified xylanase were examined by studying the reaction rate at various substrate (xylan) concentrations $(5-40 \mathrm{mg} / \mathrm{mL})$. Substrate concentration was plotted against the reaction rate to determine whether the enzyme obeys Michaelis-Menten kinetics, and $K_{\mathrm{m}}$ and $V_{\max }$ were determined from the Lineweaver-Burk plot.

For studying the effect of temperature on xylanase activity, the enzyme assay was conducted at different temperatures $\left(30-100{ }^{\circ} \mathrm{C}\right)$. The thermostability of the enzyme was examined by pre-incubating the purified enzyme (without substrate) at $60-100{ }^{\circ} \mathrm{C}$ for different intervals of time, and then assaying the residual activity.

To study the effect of $\mathrm{pH}$ on xylanase activity, the substrate used in enzyme assay was prepared in different buffers $(10 \mathrm{mM})$ such as citrate buffer ( $\mathrm{pH} \mathrm{3,} \mathrm{4,} 5$ and 6), tris buffer $(\mathrm{pH} \mathrm{7,} 8$ and 9) and glycine- $\mathrm{NaOH}$ buffer $(\mathrm{pH}$ 10). For determining $\mathrm{pH}$ stability, the enzyme (without substrate) was pre-incubated at different $\mathrm{pH}(6-10)$ using appropriate buffers, for varying time periods, and then assayed for the residual activity.

To determine the effect of various ions/additives on xylanase activity, either of the ion/additive such as $\mathrm{FeS}$ $\mathrm{O}_{4} \cdot 7 \mathrm{H}_{2} \mathrm{O}, \quad \mathrm{NH}_{4} \mathrm{Cl}, \quad \mathrm{ZnSO}_{4} \cdot 7 \mathrm{H}_{2} \mathrm{O}, \quad \mathrm{MnSO}_{4} \cdot \mathrm{H}_{2} \mathrm{O}, \mathrm{CaCl}_{2}$. $2 \mathrm{H}_{2} \mathrm{O}, \mathrm{MgSO}_{4} \cdot 7 \mathrm{H}_{2} \mathrm{O}$, SDS or ethylenediaminetetraacetic acid (EDTA) was included individually in the enzyme 
assay reaction mixture at final concentration of $10 \mathrm{mM}$, and activity assay was conducted.

All the analytical experiments were set up in triplicates and data presented is the mean of three different experiments.

\section{Results and discussion}

Xylanolytic organism, growth profile and time-course of xylanase production

Out of 40 fungal isolates screened, MA28 (the isolate from soil beneath big heap of rice husk from a rice mill) was selected for detailed studies as it showed the highest xylanase activity qualitatively as well as under submerged fermentation (at alkaline $\mathrm{pH}$ ). The identity of the isolate was established on the basis of macro (colony, growth, exudates, reverse colour, etc.) and micro (heads, condiphores, phialides, vesicles, conidia etc.) morphological characteristics (Raper and Fennell 1965). Fungal colonies on xylan agar, and on Czapek's Yeast Autolysate agar were fast spreading, powdery, initially white turning castor-grey to grayish-green later with the development of conidial heads, and reverse was faintly pale. Conidial heads were mostly columnar, conidiophores were smooth, with $300 \mu \mathrm{m}$ length and 4.8-8.0 $\mu \mathrm{m}$ wide, gradually enlarging upward and ending into the apical flask shaped vesicles (diameter 19.2-32.0 $\mu \mathrm{m}$ ), usually fertile on three quarters, uniseriate, phialides $6.4-8.0$ to $1.6-3.2 \mu \mathrm{m}$; conidia were bluish green, globose to subglobose, echinulate, mostly 2.4-3.2 $\mu \mathrm{m}$ in diameter, sclerotia or cleistothecia were absent. Based on the characteristics, the fungal strain was identified as Aspergillus fumigatus. To confirm the identity of the organism further, ITS sequence (ITS 1 region, 5.8S rRNA gene and ITS 2 region) was amplified (593 base pair sequence) and compared with that available in GenBank data base using Mega BLAST (NCBI). The obtained sequence showed $100 \%$ homology with available sequence of A. fumigatus (AF176662.1) in GenBank database. The sequence has been deposited in GenBank under accession number JN112377. The isolate MA28 was designated as A. fumigatus MA28. Recently, various fungal isolates have been reported to be excellent xylanase producers (Sudan and Bajaj 2007; Fang et al. 2010; Antoine et al. 2010; Shi et al. 2011; Bajaj et al. 2011). A thermostable xylanase from a newly isolated thermophilic fungus Talaromyces thermophilus was purified and characterized (Maalej et al. 2009).

The time-course of growth and xylanase production by A. fumigatus MA28 showed that for initial $120 \mathrm{~h}$ growth was slow and there was no xylanase production. Xylanase production commenced after $144 \mathrm{~h}(3,000 \mathrm{U} / \mathrm{L})$ and increased steeply and reached to the maximum level after $168 \mathrm{~h}$ (7,500 U/L). After $192 \mathrm{~h}$, xylanase activity suffered a slight decrease $(6,500 \mathrm{U} / \mathrm{L})$, however, afterwards xylanase activity decreased sharply (Fig. 1). The abrupt decrease in xylanase activity may be attributed to the activation of certain proteases or to the interaction of xylanase with some other medium/cell-secreted components or due to the inhibition of the enzyme by the end products (PeixotoNogueira et al. 2009). Growth and product formation share quite complex relationship, at times they go-parallel while sometimes show partial-association (Nizamudeen and Bajaj 2009). Furthermore, optimal time for maximum enzyme production varies from organism to organism. Penicillium canescens showed maximum xylanase production after 192 h of incubation (Antoine et al. 2010) while Fusarium solani F7 (Gupta et al. 2009) and Aspergillus sydowii SBS 45 (Nair et al. 2008) did so after 6 and 9 days of fermentation, respectively. Aspergillus niveus RS2 yielded maximum xylanase after 5 days of fermentation (Sudan and Bajaj 2007). Thus, it may be understood that time for maximum enzyme production depends on the type of the microbial strain, cultural and environmental conditions and genetic make-up/or potential of the organism (PeixotoNogueira et al. 2009; Bajaj and Singh 2010). Furthermore, the enzyme preparation altogether lacked CMCase and FPase activities. It is pertinent to mention here that when the intended application of the xylanase is in the pulp and

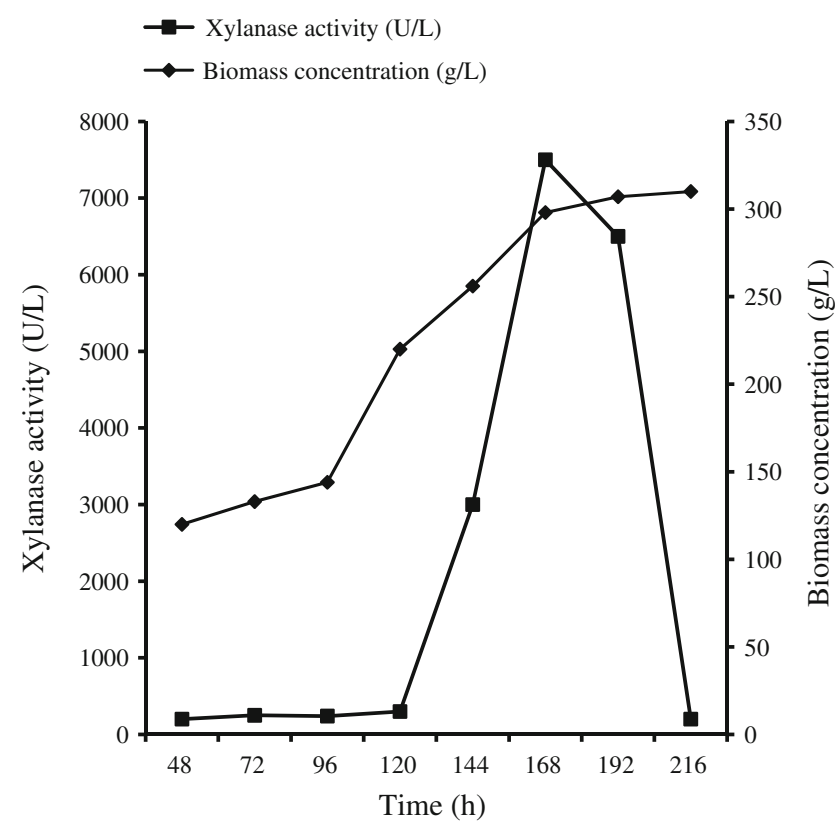

Fig. 1 Growth and time-course of xylanase production by Aspergillus fumigatus MA28. The organism was cultivated under shaking $(180 \mathrm{rpm})$ at $30^{\circ} \mathrm{C}$. Amount of biomass was determined on dry weight basis (in hot air oven at $90{ }^{\circ} \mathrm{C}$ ), and xylanase activity was assayed by determining the ability of enzyme to cause release of reducing sugars from xylan 
paper industry, the enzyme must be free of cellulolytic activity else the cellulose fibres may be damaged. There are many reports where-in cellulase-free xylanases have been reported from fungi (Dutta et al. 2007). However, negligible or significant contamination of fungal xylanases with cellulases has also been reported (Ruckmanl and Rajendran 2001; Sudan and Bajaj 2007).

Xylanase production using various carbon sources

The cost of the substrate plays a critical role in determining the overall economics of enzyme production. Low-value agriculture-based raw materials have been extensively explored as substrates for microbial enzyme production (Bajaj and Singh 2010; Pal and Khanum 2010; Bajaj and Sharma 2011; Bajaj et al. 2011). A. fumigatus MA28 showed varying level of cellulase-free xylanase production on all the agro-based substrates examined in this study (Fig. 2). Wheat bran was found to be the best inducer of xylanase and remarkably performed even better than pure xylan (activity: $8,450 \mathrm{U} / \mathrm{L}$ on wheat bran vs. $7,500 \mathrm{U} / \mathrm{L}$ on xylan), and was followed by rice bran $(5,500 \mathrm{U} / \mathrm{L})$, rice straw $(4,600 \mathrm{U} / \mathrm{L})$ and corn cobs $(4,500 \mathrm{U} / \mathrm{L})$. Thus, among the agro-wastes, wheat bran holds the greatest promise for cost-effective production of the xylanase besides it may also provide a substantial quantity of soluble arabinoxylans. Reports in literature suggest that pure xylan can be an excellent carbon source, which not only results in increased yield of xylanase but often causes a selective induction of xylanase with no or little formed cellulase (Sudan and Bajaj 2007). Wheat bran has been used as substrate for xylanase production from various organisms including A. niveus RS2 (Sudan and Bajaj 2007), A. sydowii SBS 45 (Nair et al. 2008), A. niger DFR-5 (Pal and Khanum 2010), Rhizopus var. microsporus 595 (Shuvaeva and Sysoeva
2010) and Streptomyces sp. 7b (Bajaj and Singh 2010). Evaluation of xylanase production by A. fumigatus RP04 and $A$. niveus RP05 showed that the former produced high level of xylanase on agricultural residues (corncob or wheat bran), whereas latter produced more xylanase on birchwood xylan (Peixoto-Nogueira et al. 2009). Besides wheat bran, other agro-industrial residues like soy meal, wheat and rice straw, rice bran, wood husk, coba husk, lignocellulosic coffee by-products, corn steep liquor etc. have been employed as substrates for xylanase production from different fungi (Gupta et al. 2009; Antoine et al. 2010; Fang et al. 2010; Murthy and Naidu 2010). Thus, there is an intense focus on the valorization of agro-industrial residues for production of value-added products.

Xylanase production using various nitrogen sources

The mechanisms that govern the formation of extracellular enzymes are influenced by the availability and type of nitrogenous precursors for protein synthesis. Nitrogen source can significantly affect the $\mathrm{pH}$ of the medium during the course of fermentation which in turn may influence enzyme activity and stability. In the present study, soybean meal supported higher enzyme production $(9,000 \mathrm{U} / \mathrm{L})$ as compared to the control $(7,580 \mathrm{U} / \mathrm{L})$, while all other nitrogen sources led to reduced xylanase production (Fig. 3). Soybean meal is complex and conditioned nitrogen source and does not cause catabolite repression (Sharma and Bajaj 2005). Probably this organic nitrogen source contains majorly all kinds of amino acids which can be readily absorbed by fungal mycelia. Mustard cake is quite rarely used as a nitrogen source for enzyme production (Bajaj and Sharma 2011); in the present study it did support xylanase production though to a lesser extent (Fig. 4). Similar to our results, A. sydowii SBS 45 (Nair
Fig. 2 Xylanase production from various agriculture-based carbon sources. Fermentation was executed under shaking (180 rpm) at $30^{\circ} \mathrm{C}$. Black bar indicates xylanase production when xylan was used as carbon source $(5 \mathrm{~g} / \mathrm{L})$, while the colourless bars show xylanase production when xylan was replaced with either of the agriculture-based carbon sources $(10 \mathrm{~g} / \mathrm{L})$

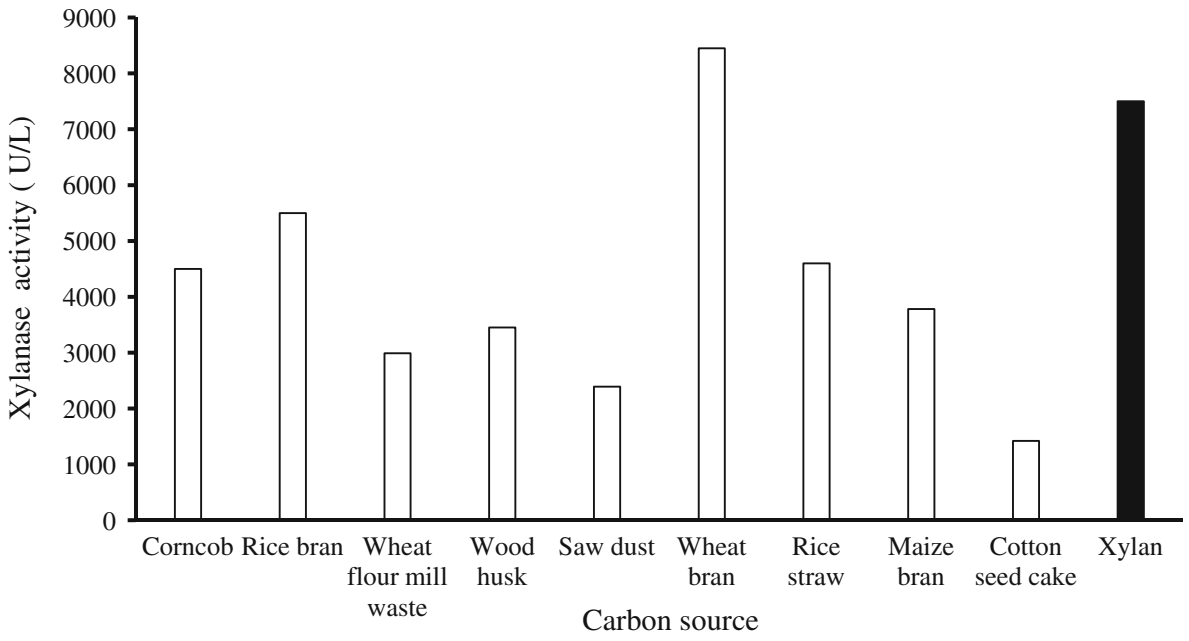

Carbon source 
Fig. 3 Xylanase production by Aspergillus fumigatus MA28 using various nitrogen sources. Fermentation was executed under shaking $(180 \mathrm{rpm})$ at $30{ }^{\circ} \mathrm{C}$. Black bar indicates xylanase production when ammonium salts (ammonium sulphate and ammonium acetate) were used as nitrogen source while the colourless bars show when ammonium salts were replaced with various nitrogen sources $(5 \mathrm{~g} / \mathrm{L})$

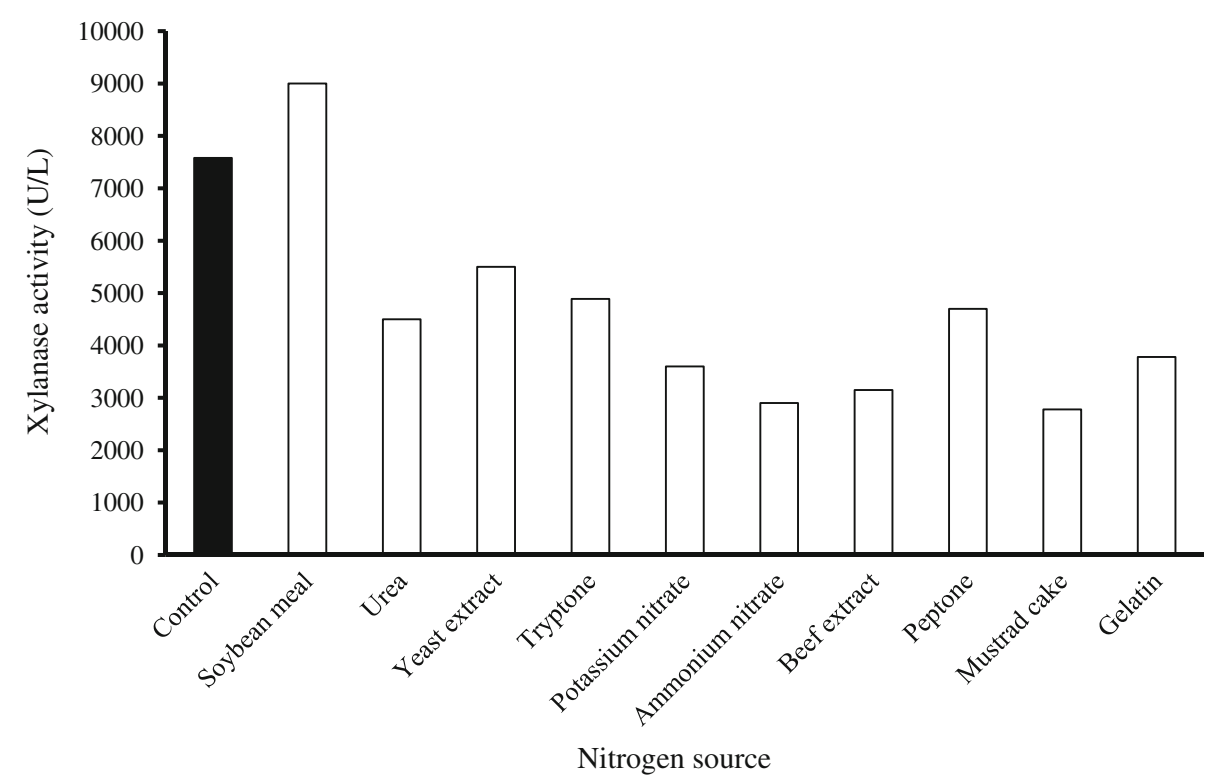

Nitrogen source

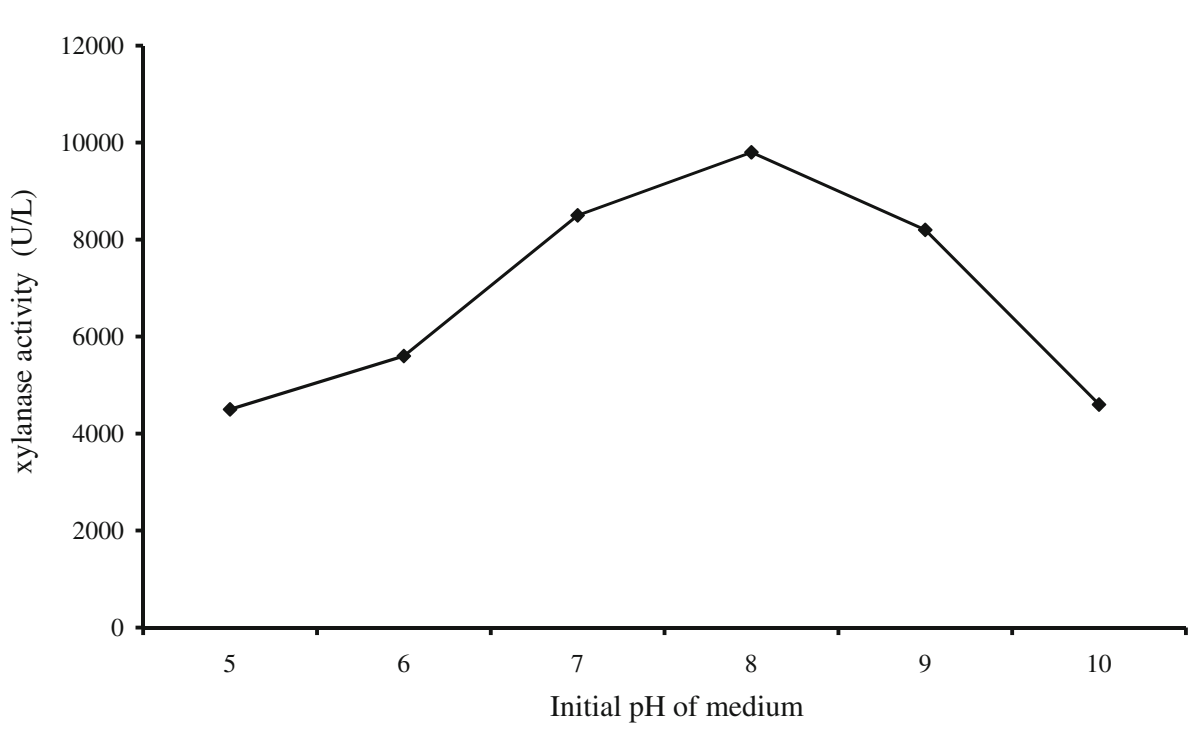

Fig. 4 Effect of initial pH of medium on xylanase production by $A$. fumigatus MA28. The initial $\mathrm{pH}$ of the production medium was adjusted at $\mathrm{pH}$ 5-10 using either $\mathrm{HCl}(0.1 \mathrm{M})$ or $\mathrm{NaOH}(0.1 \mathrm{M})$, and fermentation was carried out under shaking (180 rpm) at $30{ }^{\circ} \mathrm{C}$ et al. 2008) showed maximum xylanase production when soybean meal was employed as nitrogen source. However, A. niveus $\mathrm{RS} 2$ produced maximum xylanase when yeast extract was used as nitrogen source (Sudan and Bajaj, 2007). Penicillium canescens (Antoine et al. 2010) preferred casein, peptone and soybean meal as nitrogen sources for maximum xylanase production while Penicillium sp. CFR 303 (Murthy and Naidu 2010) performed best with peptone as nitrogen source.

Effect of initial medium $\mathrm{pH}$ on xylanase production

Medium $\mathrm{pH}$ has got profound influence on the organism's growth as well as on its ability for enzyme production. Unfavourable $\mathrm{pH}$ may not allow adequate growth and can also influence the activity and stability of enzyme. Fermentation was carried out in production medium at different $\mathrm{pH}$ values (5-10). Though, maximum xylanase production was observed in medium with $\mathrm{pH} 8(9,800 \mathrm{U} / \mathrm{L})$, substantial xylanase titre was observed at pH 9 (8,200 U/L) and pH 10 also (4,600 U/L) (Fig. 4). Majority of researchers have reported acidic $\mathrm{pH}(5-6.5)$ as the most appropriate for maximum enzyme production from fungi (Gupta et al. 2009; Murthy and Naidu 2010). However, A. niveus RS2 (Sudan and Bajaj 2007), A. flavus (Ruckmanl and Rajendran 2001) and A. sydowii SBS 45 (Nair et al. 2008) exhibited maximum production of xylanase at $\mathrm{pH} 8,9$ and 10, respectively. In the present investigation, A. fumigatus MA28 has showed sufficient alkalitolerance and capability to grow and produce enzyme at alkaline $\mathrm{pH}$. 
Purification of xylanase

Variety of approaches such as salt precipitation, ion exchange chromatography, gel filtration chromatography etc. have been employed for purification of enzymes (Nair et al. 2008; Gupta et al. 2009; Bajaj and Singh 2010; Bajaj and Sharma 2011). In the present study, AS precipitation of xylanase showed maximum activity at $20 \%$ saturation, and led to purification of xylanase by 7.95 -fold (Table 1). CMcellulose chromatography $(3.5 \times 50 \mathrm{~cm})$ further increased the purification of xylanase (fraction V) by 38.5-fold (Fig. 5; Table 1). Native-PAGE analysis of fraction $\mathrm{V}$ from CM-cellulose chromatography showed the presence of a single band on the stained half of duplicate native gel while the unstained half showed positive zymogram reaction (appearance of zone of clearance on xylan agar plate after Congo red staining). SDS-PAGE analysis showed the presence of single band of molecular weight of approximately $14.4 \mathrm{kDa}$. Similar to the present study, xylanase from A. niveus RS2 was purified by AS precipitation and CM-sephdex chromatography by 5.08 -fold, and the enzyme had a molecular weight of $22.5 \mathrm{kDa}$ (Sudan and Bajaj 2007). A. sydowii SBS 45 xylanase was purified by 93.41-times by using AS precipitation, gel filtration and anion exchange chromatography. Antoine et al. (2010) purified xylanase from $P$. canescens by 1.39 -fold using AS precipitation. Purified xylanase from $F$. solani $\mathrm{F} 7$ yielded a single band with a molecular weight of $89 \mathrm{kDa}$ (Gupta et al. 2009).

\section{Kinetic parameters}

Analysis of kinetic parameter of purified xylanase from A. fumigatus MA28 showed that it had $K_{\mathrm{m}}$ of $4.9 \mathrm{mg} / \mathrm{mL}$ and $V_{\max }$ of $980 \mu \mathrm{mol} / \mathrm{min} / \mathrm{mg}$ protein. Nair et al. (2008) studied the kinetic parameters of two xylanases from A. sydowii SBS 45 and reported that $K_{\mathrm{m}}$ value of xylanase I for birch wood xylan was $3.18 \mathrm{mg} / \mathrm{mL}$ and for oat spelt xylan $6.45 \mathrm{mg} / \mathrm{mL}$, while the $K_{\mathrm{m}}$ value of xylanase II for birch wood xylan was $6.51 \mathrm{mg} / \mathrm{mL}$ and for oat spelt xylan $7.69 \mathrm{mg} / \mathrm{mL}$. $V_{\max }$ of xylanase I and II for birch wood xylan was 1,191 and $1,587 \mu \mathrm{mol} / \mathrm{min} / \mathrm{mg}$ protein, respectively. $V_{\max }$ of xylanase I and II for oat spelt xylan was 2,604 and 2,381 $\mu \mathrm{mol} / \mathrm{min} / \mathrm{mg}$ protein, respectively. Penicillium sp. CFR 303 showed $K_{\mathrm{m}}$ of $5.6 \mathrm{mg} / \mathrm{mL}$, and $V_{\max }$ of $925 \mu \mathrm{mol} / \mathrm{min} / \mathrm{mg}$ with birchwood xylan as a substrate

Table 1 Purification of xylanase from Aspergillus fumigatus MA-28

\begin{tabular}{lllllll}
\hline Purification step & $\begin{array}{l}\text { Fraction } \\
\text { volume }(\mathrm{mL})\end{array}$ & $\begin{array}{l}\text { Total protein } \\
(\mathrm{mg})\end{array}$ & $\begin{array}{l}\text { Activity } \\
(\mathrm{U})\end{array}$ & $\begin{array}{l}\text { Specific activity } \\
(\mathrm{U} / \mathrm{mg} \text { protein) }\end{array}$ & $\begin{array}{l}\text { Purification } \\
\text { fold }\end{array}$ & $\begin{array}{l}\text { Recovery } \\
(\%)\end{array}$ \\
\hline Crude enzyme & 500 & 875 & 350 & 0.4 & 1 & 100 \\
Ammonium sulphate precipitation & 8 & 16.4 & 52.24 & 3.18 & 7.95 \\
Carboxymethyl cellulose chromatography & 4 & 2.0 & 30.8 & 15.4 & 38.5 & 8.8 \\
\hline
\end{tabular}

All the purification steps were executed at $4{ }^{\circ} \mathrm{C}$

Fig. 5 Specific activity of xylanase in different fractions eluted from carboxymethyl cellulose chromatography column. Elution was done by using increasing concentration of $\mathrm{NaCl}(0.25-1 \mathrm{M})$ solution

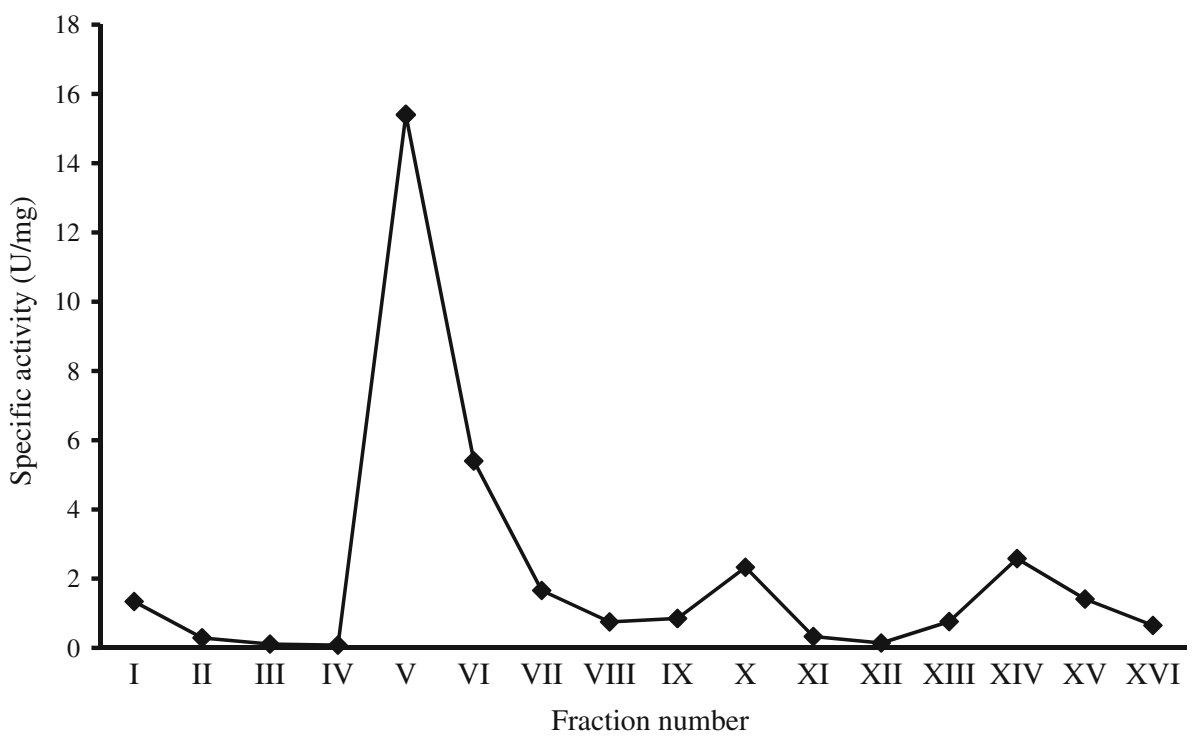

Springer 
(Murthy and Naidu 2010). The xylanase from A. niveus RS2 had $K_{\mathrm{m}}$ and $V_{\max }$ values of $2.5 \mathrm{mg} / \mathrm{mL}$ and $26 \mu \mathrm{mol} /$ $\mathrm{mg} / \mathrm{min}$, respectively (Sudan and Bajaj 2007).

Effect of temperature on xylanase activity

Activity assay at different temperatures $\left(30-100{ }^{\circ} \mathrm{C}\right)$ indicated that A. fumigatus MA28 xylanase exercises maximum activity at $50{ }^{\circ} \mathrm{C}(9,800 \mathrm{U} / \mathrm{L})$, however, significant activity was observed at $60{ }^{\circ} \mathrm{C}(8,200 \mathrm{U} / \mathrm{L})$ and $70{ }^{\circ} \mathrm{C}$ $(4,600 \mathrm{U} / \mathrm{L})$ also (Fig. 6). However, at still higher temperatures $\left(70-100{ }^{\circ} \mathrm{C}\right)$ reduction in enzyme activity occurred. Several fungal xylanases have been reported to show optimum activity at $50{ }^{\circ} \mathrm{C}$ (Srinivasan and Rele 1999; Dutta et al. 2007; Nair et al. 2008; Murthy and Naidu 2010). However, xylanases from A. tubingensis and A. terreus showed optimum activity at $65^{\circ} \mathrm{C}$ (Bakri et al.
2010), and those from A. fumigatus and A. niveus displayed optima at $60-70{ }^{\circ} \mathrm{C}$ (Peixoto-Nogueira et al. 2009). Similarly, Maalej et al. (2009) reported temperature optima of 75-80 ${ }^{\circ} \mathrm{C}$ for T. thermophilus xylanase.

\section{Effect of $\mathrm{pH}$ on enzyme activity}

Activity of the purified xylanase was assayed at different $\mathrm{pH}(3-10)$ by using appropriate buffers. It was remarkable to observe that enzyme activity increased continuously with increase in $\mathrm{pH}$ from 3 to 8 and reached maximum at pH 8 (9,700 U/L) as shown in Fig. 7. Nonetheless significant enzyme activity was observed at $\mathrm{pH} 9(8,300 \mathrm{U} / \mathrm{L})$ and pH 10 (4,200 U/L). Results indicate very alkaliphilic feature of enzyme. It is worth mentioning here that A. fumigatus MA28 xylanase has major levels of alkalistability and thus, could be of potential importance for pulp
Fig. 6 Effect of temperature on activity of A. fumigatus MA28 xylanase. Activity assay was conducted at different temperatures $\left(30-100^{\circ} \mathrm{C}\right)$ by incubating the enzyme assay mixture in water bath set at appropriate temperature
Fig. 7 Effect of pH on activity of $A$. fumigatus MA28 xylanase. The activity assay was conducted at different $\mathrm{pH}$ (3-10) using appropriate buffers. The substrate solution used in the enzyme assay mixture was prepared either in citrate buffer ( $\mathrm{pH} \mathrm{3,4,5}$ and 6), tris buffer ( $\mathrm{pH} \mathrm{7,8}$ and 9) or glycine- $\mathrm{NaOH}$ (pH 10) to expose the enzyme to different $\mathrm{pH}$
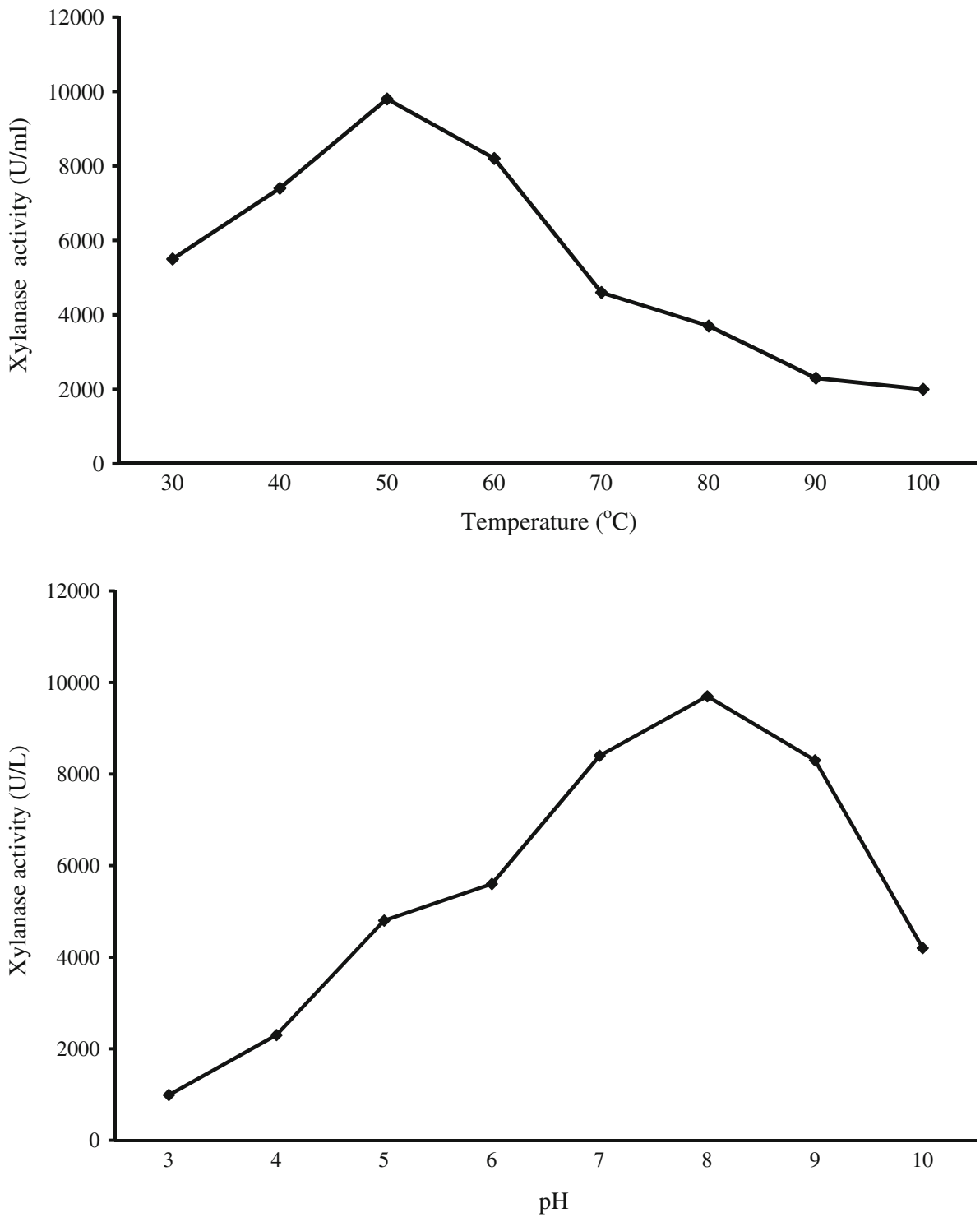
bleaching applications. Generally, microbial xylanases show activity in acidic or neutral range. The $\mathrm{pH}$ optima of the xylanases from A. fumigatus and A. niveus (PeixotoNogueira et al. 2009), from $F$. solani $\mathrm{F} 7$ (Gupta et al. 2009) and from Penicillium sp. CFR 303 (Murthy and Naidu 2010) was in acidic range i.e. 4.5-5.5. However, xylanase from A. niveus RS2 (Sudan and Bajaj 2007) showed pH optima of 7 while those from A. tubingensis and A. terreus showed optimum activity at pH 8 (Bakri et al. 2010). Similarly, T. thermophilus xylanase exhibited optimum activity at pH 7-8 (Maalej et al. 2009). In contrast, $P$. citrinum xylanase (Dutta et al. 2007) and two xylanases from A. sydowii SBS 45 (Nair et al. 2008) showed optimum activity at $\mathrm{pH} 8.5$ and 10 , respectively.

Thermostability and $\mathrm{pH}$ stability of xylanase

A. fumigatus MA28 xylanase showed thorough stability at $50{ }^{\circ} \mathrm{C}(100 \%)$. At $60-70{ }^{\circ} \mathrm{C}$, considerable high activity was observed after $30 \mathrm{~min}(68-75 \%)$ and $60 \mathrm{~min}(40-53 \%)$ of pre-incubation. However, at still higher temperatures $\left(80-100{ }^{\circ} \mathrm{C}\right)$ the residual activity decreased significantly particularly after $60 \mathrm{~min}$ of incubation (residual activity: $14-21 \%$ ) but up to $30 \mathrm{~min}$ the enzyme retained relatively higher activity (30-40\%) as presented in the Fig. 8. The results indicate that the xylanase from A. fumigatus MA28 is moderately thermostable and may have potential for application in industrial processes. A. foetidus xylanase retained 71 and $20 \%$ of the activity after $30 \mathrm{~min}$, at 50 and $60{ }^{\circ} \mathrm{C}$, respectively, however, at $70{ }^{\circ} \mathrm{C}$ enzyme was completely inactivated within $30 \mathrm{~min}$ (Shah and Madamwar 2005). Penicillium sp. ECU0913 xylanase showed good

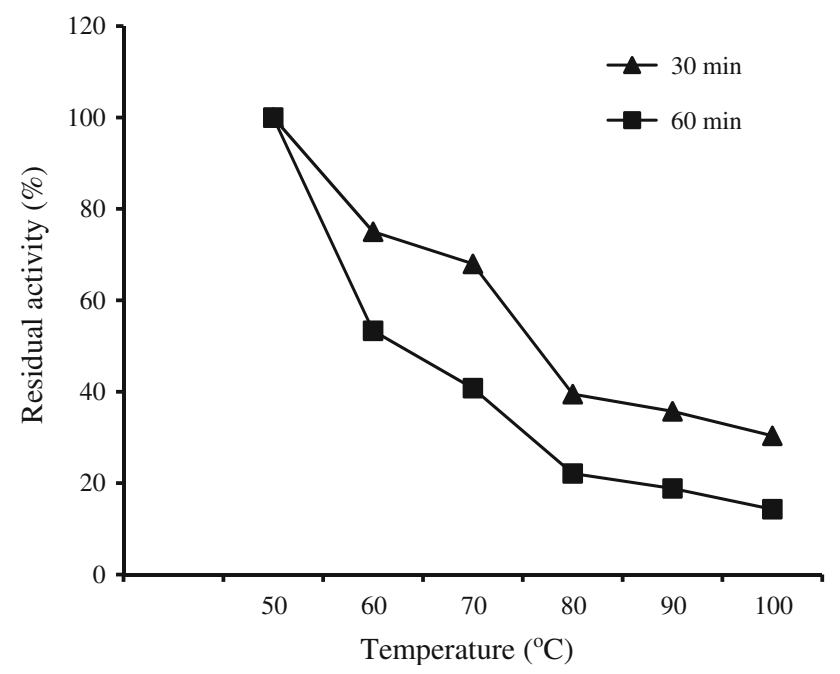

Fig. 8 Thermostability of A. fumigatus MA28 xylanase. The enzyme (without substrate) was pre-incubated at different temperatures $\left(50-100{ }^{\circ} \mathrm{C}\right)$ for varying time periods $(30$ and $60 \mathrm{~min})$ and then assayed for residual activity. Initial activity was considered as $100 \%$ stability for 2 days at $25{ }^{\circ} \mathrm{C}$ but after 1 week residual activity was $65 \%$ (Shi et al. 2011). Xylanase I and II from A. sydowii SBS 45 showed maximum stability at $30{ }^{\circ} \mathrm{C}$ for $4 \mathrm{~h}$ (Nair et al. 2008). Xylanases from A. fumigatus and A. niveus showed high stability at $60^{\circ} \mathrm{C}$ for $30 \mathrm{~min}$ (95-98\% of the initial activity), however, $60 \mathrm{~min}$ preincubation at this temperature caused considerable activity reduction (Peixoto-Nogueira et al. 2009).

$\mathrm{pH}$ stability analysis of xylanase showed that residual activity of xylanase after $30 \mathrm{~min}$ was substantial at $\mathrm{pH} 8$ (88\%), moderate at $\mathrm{pH} 9(56 \%)$ and low at $\mathrm{pH} 10(29 \%)$. In general, the enzyme was moderately stable up to $30 \mathrm{~min}$ at $\mathrm{pH}$ 6-9 as shown in Fig. 9. However, $60 \mathrm{~min}$ pre-incubation of enzyme at alkaline $\mathrm{pH}$ caused considerable activity reduction. In contrast, both xylanases I and II from A. sydowii SBS 45 showed broad $\mathrm{pH}$ (4-11) stability for 30 min- $1 \mathrm{~h}$ (Nair et al. 2008). The pH stability of the xylanase from A. fumigatus was higher at $\mathrm{pH}$ 6.0-8.0, while the enzyme from A. niveus was more stable at pH 4.5-6.5 (Peixoto-Nogueira et al. 2009). Maximum stability of $R$. var. microsporus 595 xylanase was observed in the $\mathrm{pH}$ range of 5.0-6.0 (Shuvaeva and Sysoeva 2010).

\section{Effect of various additives on xylanase activity}

Various cations $\left(\mathrm{Mg}^{2+}, \mathrm{Ca}^{2+}, \mathrm{Mn}^{2+}, \mathrm{Zn}^{2+}, \mathrm{NH}_{4}{ }^{+}, \mathrm{Fe}^{2+}\right)$ or additives (SDS and EDTA) were individually included in the assay mixture at final concentration of $10 \mathrm{mM}$, and activity assayed. $\mathrm{Fe}^{2+}$ enhanced the activity of xylanase by $40 \%$. EDTA and $\mathrm{Mg}^{2+}$ moderately inhibited the xylanase and resulted in loss of activity by 65 and 58\%, respectively (Fig. 10). All the other cations showed more or less

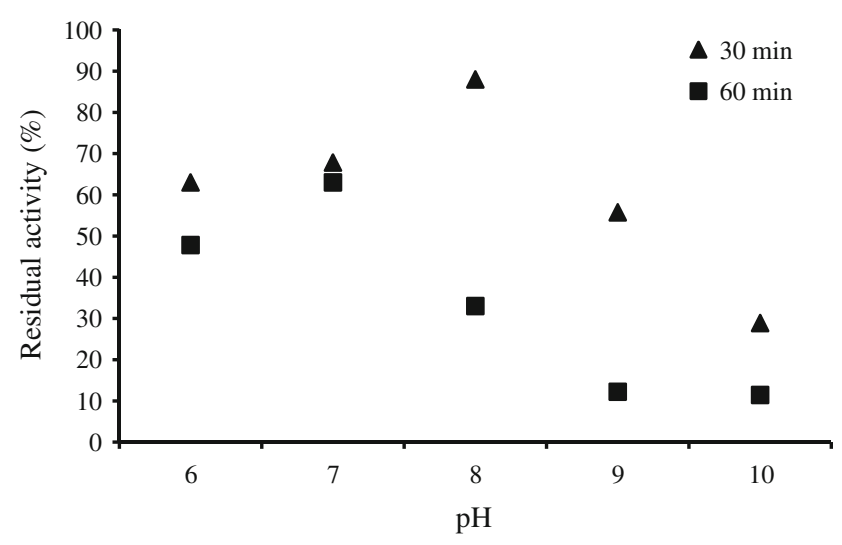

Fig. 9 Stability of A. fumigatus MA28 xylanase at different $\mathrm{pH}$. The enzyme (without substrate) was pre-incubated for 30 and $60 \mathrm{~min}$ at different $\mathrm{pH}$ using appropriate buffers: citrate buffer ( $\mathrm{pH}$ 6), tris buffer ( $\mathrm{pH} \mathrm{7,} 8$ and 9) and glycine- $\mathrm{NaOH}$ ( $\mathrm{pH} \mathrm{10),} \mathrm{and} \mathrm{then} \mathrm{assayed}$ for residual activity. Initial activity was considered as $100 \%$ 
Fig. 10 Effect of various additives and cations on xylanase activity. Black bar indicates activity without any additive/ion (control) while the colourless bars show xylanase activity when either of the additive or ion was included in enzyme assay mixture at final concentration of $10 \mathrm{mM}$

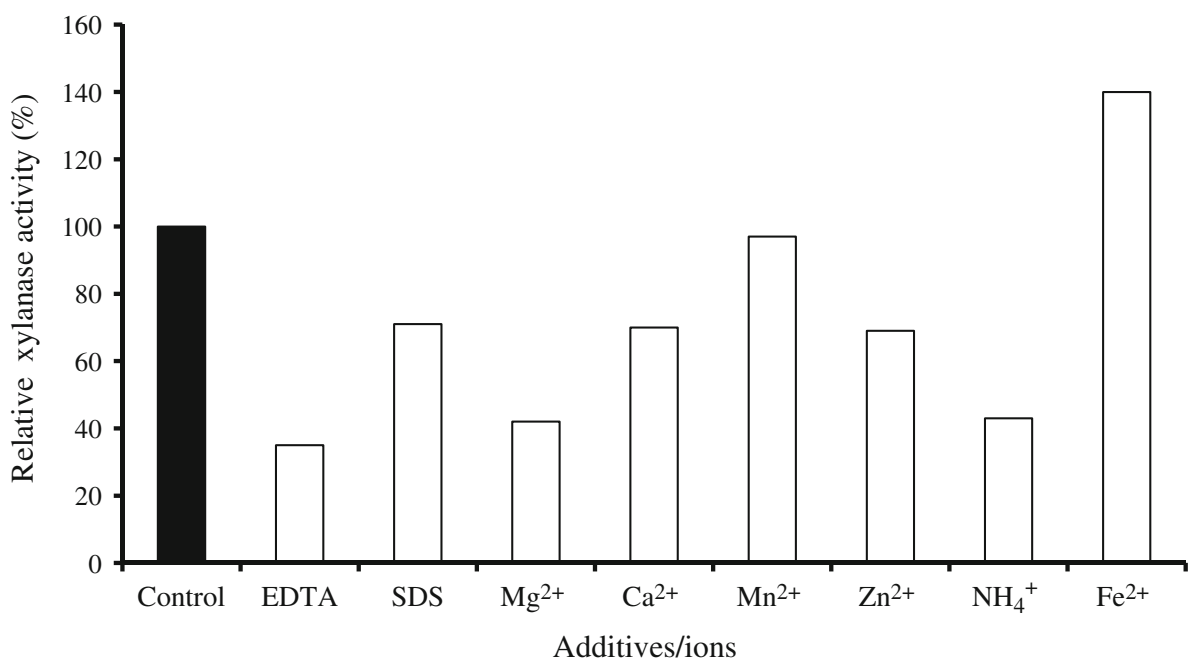

inhibitory effect on xylanase activity. Negligible loss of activity (3\%) was caused by $\mathrm{Mn}^{2+}$, while $\mathrm{Ca}^{2+}$ and $\mathrm{Zn}^{2+}$ decreased xylanase activity by 30 and $31 \%$, respectively. SDS decreased enzyme activity by $29 \%$. The decrease in enzyme activity may be due to involvement of cations/ additives with the structure and conformation of the enzyme. Metals like $\mathrm{Al}^{3+}, \mathrm{Ba}^{2+}, \mathrm{Ca}^{2+}, \mathrm{Na}^{+}$and $\mathrm{Zn}^{2+}$ enhanced the activity of xylanase I and II from A. sydowii SBS 45 at $10 \mathrm{mM}$ concentration (Nair et al. 2008). All three purified iso-xylanases from Myceliophthora sp. IMI 387099 showed enhanced activity in presence of $\mathrm{Na}^{+}$, $\mathrm{Mg}^{2+} \mathrm{Mn}^{2+}$ and $\mathrm{K}^{+}$ions, whereas, $\mathrm{Zn}^{2+}$ and $\mathrm{Cu}^{2+}$ showed negative effect on Xyl IIa. The activity of Xyl IIa increased in presence of reducing agents dithiothreitol and mercaptoethanol, however, SDS showed inhibitory effect (Badhan et al. 2008). Activity of A. niveus RS2 was enhanced in the presence of $\mathrm{Mn}^{2+}$ ions while $\mathrm{Hg}^{2+}$ ions strongly inhibited the enzyme; other ions like $\mathrm{Co}^{2+}, \mathrm{Ca}^{2+}, \mathrm{NH}_{4}^{+}, \mathrm{Fe}^{2+}$ and $\mathrm{Mg}^{2+}$ caused low to moderate activity reduction (Sudan and Bajaj 2007).

\section{Conclusion}

The present study is a step-forward towards valorization of agro-residues for the production of value-added industrial products. Among various agro-residues examined wheat bran appears to be the most promising substrate for xylanase production by A. fumigatus MA28. Furthermore, the enzyme possessed substantial thermo-alkalistability and could be of potential significance for various industries including pulp and paper. Such enzymes must be studied in-depth for their structural conformation and encoding genes to decipher the molecular basis of thermoalkalistability.
Acknowledgments Dr. Bijender Kumar Bajaj gratefully acknowledges the Department of Science and Technology, Ministry of Science and Technology, Govt. of India, for financial support (Project Ref. SR/SO/BB-66/2007), and the Director, School of Biotechnology, University of Jammu, Jammu, for necessary laboratory facilities. Prof. Yash P. Sharma, Department of Botany, University of Jammu, and Dr. Yash P. Khajuria, Post Doctoral Fellow, National Institute of Plant Genome Research, New Delhi, are acknowledged for helping identify the fungus.

Open Access This article is distributed under the terms of the Creative Commons Attribution License which permits any use, distribution and reproduction in any medium, provided the original author(s) and source are credited.

\section{References}

Antoine AA, Jacqueline D, Thonart P (2010) Xylanase production by Penicillium canescens on soy oil cake in solid-state fermentation. Appl Biochem Biotechnol 160:50-62

Badhan AK, Chadha BS, Saini HS (2008) Purification of the alkaliphilic xylanases from Myceliophthora sp. IMI 387099 using cellulose-binding domain as an affinity tag. World J Microbiol Biotechnol 24:973-981

Bajaj BK, Sharma P (2011) An alkali-thermotolerant extracellular protease from a newly isolated Streptomyces sp. DP2. New Biotechnol. doi:10.1016/j.nbt.2011.01.001

Bajaj BK, Singh NP (2010) Production of xylanase from an alkalitolerant Streptomyces sp. 7b under solid-state fermentation, its purification, and characterization. Appl Biochem Biotechnol 162:1804-1818

Bajaj BK, Sharma M, Sharma S (2011) Alkalistable endo- $\beta-1$, 4-xylanase production from a newly isolated alkalitolerant Penicillium sp. SS1 using agro-residues. 3 Biotech. doi: 10.1007/s13205-011-0009-5

Bakri Y, Masson M, Thonart P (2010) Isolation and identification of two new fungal strains for xylanase production. Appl Biochem Biotechnol 162:1626-1634

Beg QK, Kapoor M, Hoondal GS (2001) Microbial xylanases and their industrial applications: a review. Appl Microbiol Biotechnol 56:326-338 
Dutta T, Sengupta R, Sahoo R, Sinha Ray S, Bhattacharjee A, Ghosh S (2007) A novel cellulase-free alkaliphilic xylanase from alkalitolerant Penicillium citrinum: production, purification and characterization. Lett Appl Microbiol 44:206-211

Fang TJ, Liao BC, Lee SC (2010) Enhanced production of xylanase by Aspergillus carneus M34 in solid-state fermentation with agricultural waste using statistical approach. New Biotechnol $27: 25-32$

Gupta VK, Gaur R, Gautam N, Kumar P, Yadav IJ, Dharmwal NS (2009) Optimization of xylanase production from Fusarium solani F7. Am J Food Technol 4:20-29

Haltrich D, Nidetzky B, Kulbe K, Steiner W, Zupancic S (1996) Production of fungal xylanases. Bioresour Technol 58:137-161

Kuhad RC, Singh A (1993) Lignocellulosic biotechnology: current and future prospects. Crit Rev Biotechnol 13:151-172

Lowry OH, Rosenbrough NJ, Farr AL, Randall RJ (1951) Protein measurement with the folin-phenol reagent. J Biol Chem 193:265-275

Maalej I, Belhaj I, Belghith H (2009) Highly thermostable xylanase of the theromphilic fungus Talaromyces thermophilus: purification and characterization. Appl Biochem Biotechnol 158:200-212

Miller GL (1959) Use of dinitrosalicylic acid for the determination of reducing sugar. Anal Chem 31:426-428

Murthy PS, Naidu MM (2010) Production and application of xylanase from Penicillium sp. utilizing coffee by-products. Food Bioprocess Technol doi: 10.1007/s11947-010-0331-7

Nair SG, Sindhu R, Shankar S (2008) Purification and biochemical characterization of two xylanases from Aspergillus sydowii SBS 45. Appl Biochem Biotechnol 149:229-243

Nizamudeen S, Bajaj BK (2009) A novel thermo-alkalitolerant endoglucanase production using cost-effective agricultural residues as substrates by a newly isolated Bacillus sp. NZ. Food Technol Biotechnol 47:435-440

Pal A, Khanum F (2010) Production and extraction optimization of xylanase from Aspergillus niger DFR-5 through solid-statefermentation. Bioresour Technol 101:7563-7569
Peixoto-Nogueira SC, Michelin M, Betini JHA, Jorge JA, Terenzi HF, Polizeli MM (2009) Production of xylanase by Aspergilli using alternative carbon sources: application of the crude extract on cellulose pulp biobleaching. J Ind Microbiol Biotechnol 36:149-155

Raper KB, Fennell DI (1965) The genus Aspergillus. Williams \& Wilkins, Baltimore

Ruckmanl A, Rajendran A (2001) Production of cellulase-poor xylanase by an alkalitolerant strain of Aspergillus flavus. Ind $\mathrm{J}$ Microbiol 41:115-118

Sambrook J, Fritsch EF, Maniatis T (1989) Molecular cloning: a laboratory manual, 2nd edn. Cold Spring Harbor Laboratory Press

Shah AR, Madamwar D (2005) Xylanase production by a newly isolated Aspergillus foetidus strain and its characterization. Process Biochem 40:1763-1771

Sharma P, Bajaj BK (2005) Production and partial characterization of alkalitolerant xylanase from an alkalophilic Streptomyces sp. CD3. J Sci Ind Res 64:688-698

Shi QQ, Sun J, Yu HL, Li CX, Bao J, Xu JH (2011) Catalytic performance of corn stover hydrolysis by a new isolate Penicillium sp. ECU0913 producing both cellulase and xylanase. Appl Biochem Biotechnol. doi:10.1007/s12010-011-9176-4

Shuvaeva GP, Sysoeva MG (2010) Xylanase of the micromycete Rhizopus var. microsporus 595: preparation, structural and functional characteristics and application. Appl Biochem Microbiol 46:641-647

Singh S, Dutt D, Tyagi CH, Upadhyaya JS (2011) Bio-conventional bleaching of wheat straw soda-AQ pulp with crude xylanases from SH-1 NTCC-1163 and SH-2 NTCC-1164 strains of Coprinellus disseminatus to mitigate AOX generation. New Biotechnol 28:47-57

Srinivasan MC, Rele MV (1999) Microbial xylanases for paper industry. Curr Sci 77:137-142

Sudan R, Bajaj BK (2007) Production and biochemical characterization of xylanase from an alkalitolerant novel species Aspergillus niveus RS2. World J Microbiol Biotechnol 23:491-500 